\title{
SOVEREIGNTY IN DRAG: On Fakes, Foreclosure, and Unbecoming States
}

\author{
REBECCA BRYANT \\ Utrecht University \\ (D) https:/ / orcid.org/0000-0002-8079-7704
}

Two checkpoints and a UN buffer zone split the most central shopping street of Nicosia, Cyprus's divided capital. Before the island's conflict began, Ledra Street was an artery of trade in the city, ${ }^{1}$ and that trade boomed again when the checkpoints dividing it opened to pedestrian traffic in 2008, after almost forty-five years of closure. Today, if you walk through that war-scarred border area, you also cross the threshold between life in a recognized EU-member state in the island's south, the Republic of Cyprus (RoC), and an unrecognized state in its north, the "Turkish Republic of Northern Cyprus" (TRNC).

One of the most commonplace manifestations of that division is also the main reason many Cypriots cross the line these days: the opportunity to eat, drink, and especially shop on "the other side." While many Turkish Cypriots cross to the south to visit Starbucks and McDonald's, or to shop at H\&M, many Greek Cypriots cross to the north to eat Turkish kebabs, buy cheap gasoline and medications, and select from a wide variety of name-brand knockoffs. Indeed, the "pirate state" in the island's north has long been a center for pirated goods, so that when you cross the checkpoint into the city's north, you enter a realm in which the socalled real and the so-called fake become almost indistiguishable. ${ }^{3}$ 


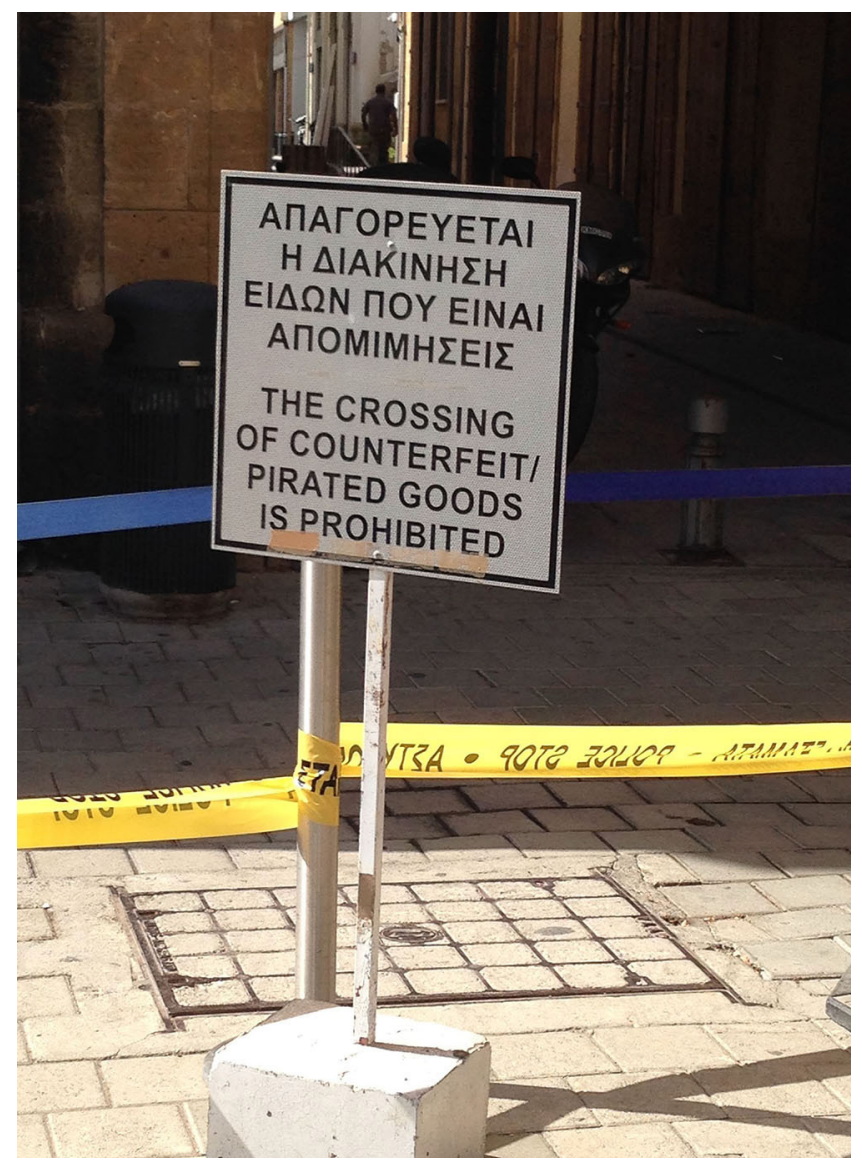

Figure 1. A sign at the Ledra Street checkpoint prohibiting the crossing of counterfeit goods into Nicosia's south. Photo by Rebecca Bryant.

One day as I was crossing from south to north my attention was drawn to some sport shoes whose design, stitching, and labeling all made them look remarkably like the "real thing." A shop assistant, a young woman, caught me staring at the shoes and inquired if I would like to try them on. I asked her, "These are not real, right?" She smiled with a slightly embarassed, conspiratorial glance and said no. I inquired if they were made in Turkey. "Yes, of course," she replied. "And the real ones are also made in Turkey, aren't they?" I asked. This had been a source of confusion to me for some time, because with the expansion of Turkey's textile sector, many global brands such as Levi's or Benetton have production operations in that country. This had left me wondering if perhaps the products that looked so real but were supposedly fake might actually be discards, leftovers, or extra production from these factories (see also Crăciun 2012). 


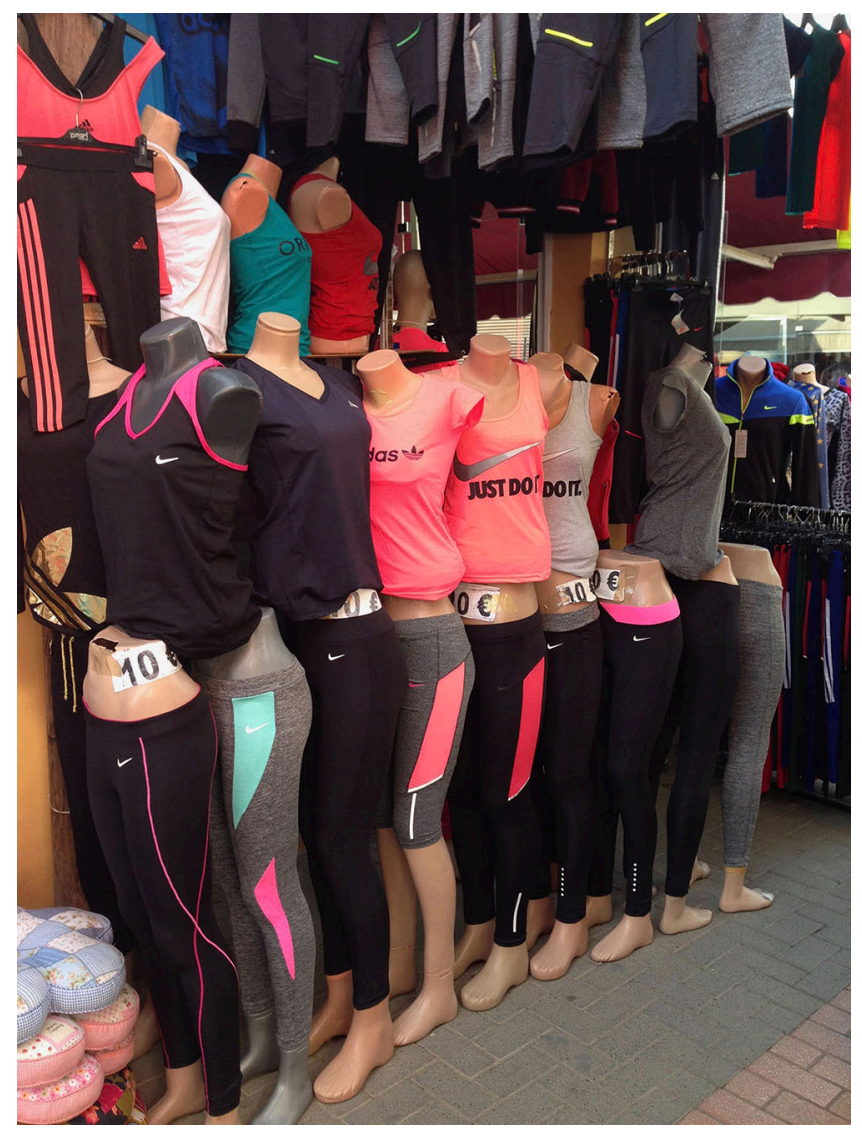

Figure 2. Some of the assortment of "brands" available in the island's north. Photo by Rebecca Bryant.

"Yes," this young woman clarified for me, "they're made in Turkey, but in different factories." I nodded, and just to be polite asked if I might try on a pair of "Nikes." She ushered me into the shop, stacked high with pirated items.

When she brought out the shoes, I pursued the topic. "So, what's the biggest difference between these shoes and the real thing?"

"It's the quality," she answered. "The materials, the way they're made."

And then she volunteered something that I thought even more interesting. "But none of the products that come here are the real thing."

I was a bit shocked, because outside of touristic areas such as this one, which had been a center for pirated goods since the 1980s, the post-millennium period had brought an expansion of global capital in the island's north. After the island's division in 1974, Turkish Cypriots began to move to suburbs outside the walled city, leaving the shopping district in which I found myself that day mainly to tour- 
ists, students, and laborers. And as I will explain, in the early 2000s global capital for the first time made its mark in the north in the form of new shopping malls and high-end shops and cafés.

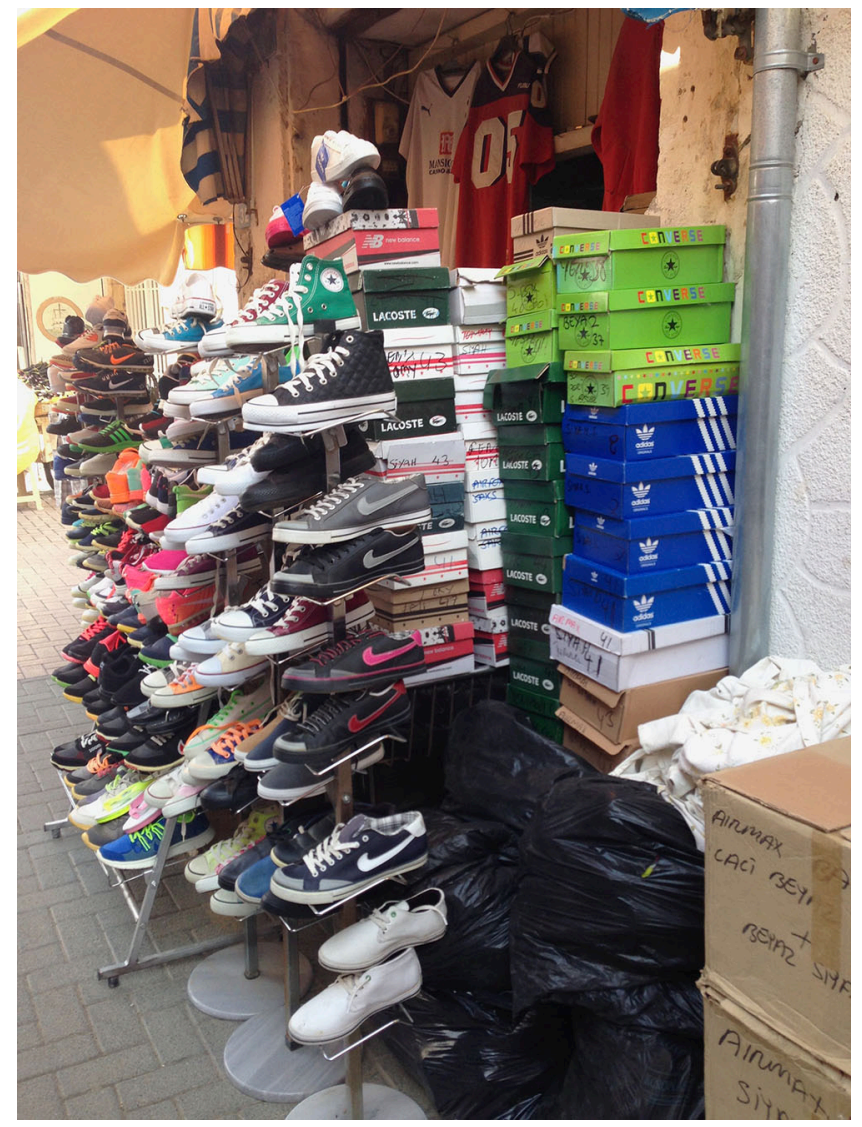

Figure 3. Labels and "labels.” Photo by Rebecca Bryant.

“So, you mean even the Nike shop in Dereboyu doesn't sell real Nikes?" I asked with some incredulity, referring to the main shopping street of north Nicosia outside the walls. Everything about the Tommy Hilfiger, Adidas, Converse, Mango, and other brand-name stores on that street - from the decorations to the promotions to of course the prices and quality — suggested that they were nothing less than real. "Do you know that for sure?"

She nodded, then looked around and smiled again in a conspiratorial way. "Last year I bought a pair of Converse from the shop there, and within a few months they started to fall apart." 


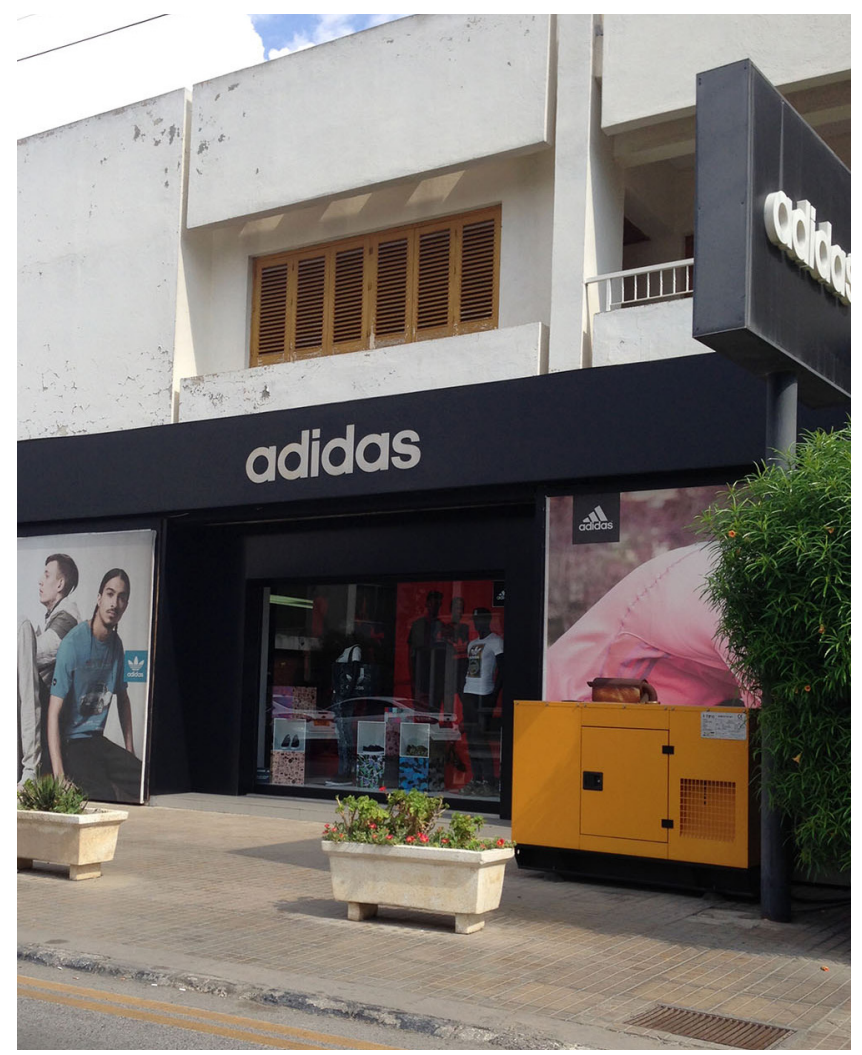

Figure 4. The "real" thing: A shop on Dereboyu, the main shopping street outside the walls in north Nicosia. Photo by Rebecca Bryant.

I remarked that I was not so sure about the lasting power of Converse in general as a brand, but I also was struck by the young woman's logic, which in fact I had heard only about an hour earlier while shopping in a brand-name shoe store in the south. In that store, two Turkish Cypriot women had been conversing while the husband of one tried on shoes. "We have Clarks and brands like that," said one, referring to shoe stores in the north, "but they're just not comfortable. Clarks are supposed to be comfortable, but these never are. I don't believe they're the real thing."

Strikingly, in both cases the failure of a "real" brand to meet expectations gets chalked up to a presumed fakeness, a quality assumed so thoroughly to permeate the island's north that it infiltrates even products we have every reason to think "real."

When I began research on Cyprus in the early 1990s, there was no chance of mistaking "fake" for "real" — or vice versa. There were no Nikes, Adidas, or other 
brand-names to be bought - except in their pirated versions. The north's status as a "pirate state" was visually and viscerally reflected in the way that in every realm of life they were faking it. In place of McDonald's you found Big Mac, in place of Pizza Hut you had Pizza Hat, in place of Kentucky Fried Chicken there was Kermiya Fried Chicken — Kermiya being a neighborhood of north Nicosia. They used similar designs, packaging, and recipes to the original, but they were fakes. And obvious ones. ${ }^{4}$

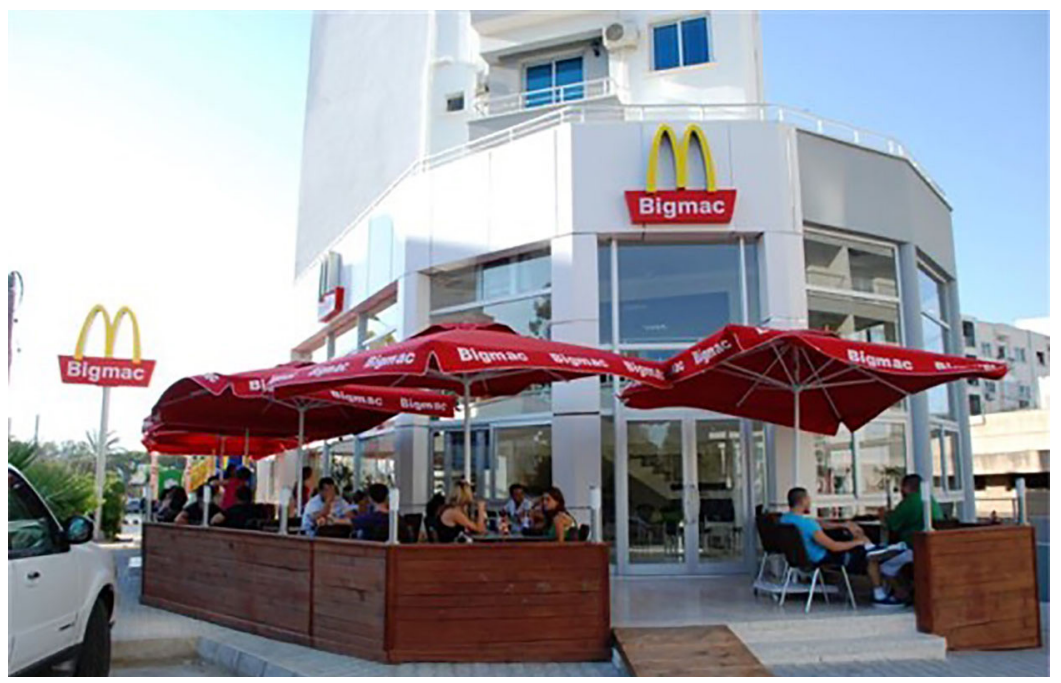

Figure 5. Signs of simulation:The now defunct Big Mac in Nicosia. Photo by Rebecca Bryant.

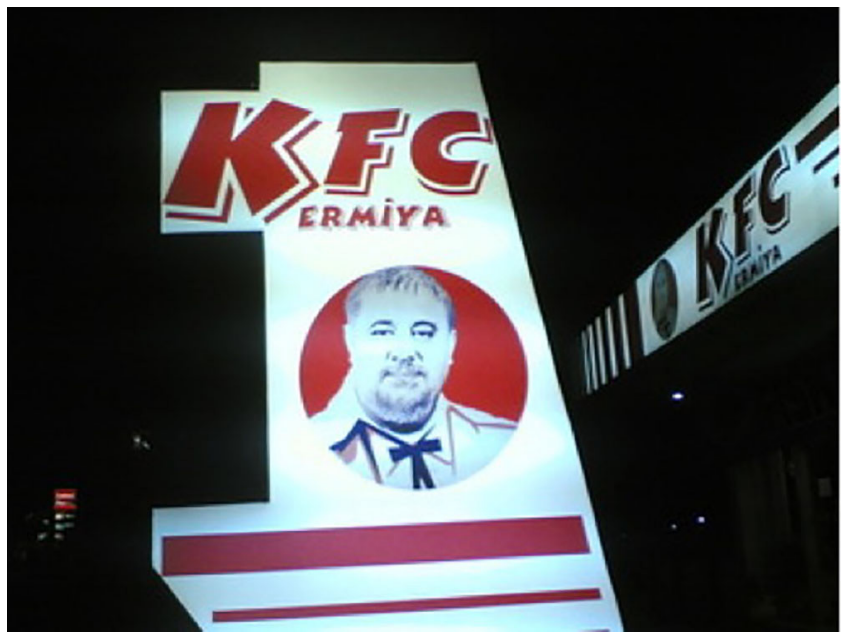

Figure 6. Kermiya Fried Chicken, also now defunct, named after a neighborhood of north Nicosia. Courtesy of Imgur. https: / /imgur.com/bZVWelE. 
My encounter with the shopgirl, then, points to a problem, or a puzzle, that I have observed because of my long-term engagement with Cyprus since the early 1990s. In the island's north, I have witnessed a transition from a period when people lived with fakeness as an everyday part of being citizens of a so-called pirate state, but where those same citizens still engaged fairly enthusiastically in statecraft, in other words, they seemed to believe in their state, to a period when the signs and symbols of fakeness have mostly disappeared from citizens' everyday lives, but they seem to doubt their state's “stateness." Friends often sardonically call their administration an uyduruk devlet, a "made-up state," a way of referring to life in the island's north as one of quotation marks and a certain kind of mimetic fabrication.

This idea of the made-up state overlaps rather neatly with an important strain of literature in the social sciences that describes the state and sovereignty as social constructs and questions their reification (see, especially, Biersteker and Weber 1996; Mitchell 1990, 1991; Weber 1992, 1995, 1998; Walker 1993, 1996). The mundane practices that perform the state and manifest sovereignty have been variously called "prosaic stateness" (Painter 2006), "tacit sovereignty" (McConnell 2009, 2016; also Wilson 2016), and "performative sovereignty" (Bobick 2017). This general acceptance that the state and sovereignty are social constructs also makes it tempting to use the so-called or pseudo state as a proxy for the made-up or make-believe (Navaro-Yashin 2012) nature of the state and sovereignty more generally.

However, uyduruk means not only made-up or fake but also jerry-built or sloppy, thus pointing not only to the state's construction but also to its deconstruction. It points to the idea of the state (Abrams 1988) that certain anthropologists have recently argued produces hope, longing, or yearning (Fehérváry 2002; Greenberg 2011; Jansen 2015), though it may also produce demoralization (Rajković 2018), ambivalence (Jovanović 2018), and cynicism (Steinmüller and Brandstädter 2015). The jerry-built state implies an entity that never quite becomes what it should be.

While I take the literature on the performance of the state as a starting point, then, my own concern is the point at which such performances succeed, or indeed, where they might fail, even for those enacting them. My argument uses examples of engagement with an unrecognized state to show how, in the context of globalization and transnational institutions, citizens of that de facto entity learn, in quotidian ways, to perform not stateness and sovereignty, but rather "stateness" 
and "sovereignty," persistently calling attention to the made-up nature of their claims.

I use ethnographic examples to develop the concept of the unbecoming - in this case, the unbecoming state, with citizens who, in the terms of popular sovereignty, are its unbecoming sovereigns. ${ }^{5}$ The concept of unbecoming is more than simply a counterpoint to the metaphysics of becoming - characterized by plasticity, potentiality, and openness - that João Biehl and Peter Locke (2010) propose should be central to anthropological theorizing. Rather, I use the unbecoming to capture a specific ethnographic modality of futurity, foreclosure, where what is to come, or what could or should come, is already ruled out. Engaging with queer theory, particularly Judith Butler's discussions of foreclosed desires, I show how performances of "stateness" most closely resemble drag and camp — and in resembling them also point us to ambiguities in the definition of supposedly real stateness. Moreover, I show how the foreclosure of particular desires to have a "real" state also orients citizens to the future (Bryant and Knight 2019), entailing forms of preemptive action that are simultaneously melancholic and parodic and that emerge when certain options are always already impossible.

\section{THE QUEER ART OF CAMPING SOVEREIGNTY}

Just a few months before the death of Rauf Denktaş, Turkish Cypriots' former president and longtime political leader, I turned on a local television channel in north Cyprus to see him in an interview. On the program, Denktaş was discussing with the host his persistent position that for Turkish Cypriots and Greek Cypriots to negotiate a settlement on a more or less equal footing, the Turkish Cypriot state needed first to be recognized, "even if only for a minute," as he used to say. The phones were ringing on the program, and he was suddenly confronted with an agitated caller who insistently asked him, "Are we sovereign? [Biz egemen miyiz?] Can you really say that we're sovereign?" The year was 2011, and by that time I had grown rather used to these expressions of disbelief in sovereignty and so did not find the caller's question very surprising. I was surprised, however, by Denktaş's pithy reply. He quipped, "If you believe you're sovereign, you're sovereign. Sovereignty is a matter of belief" (Egemen olduğuna inanırsan, egemensin. Egemenlik inanç meselesidir).

Denktaş clearly suggested sovereignty as something made up, in the sense of being performed or fabricated. Indeed, his assertion that "sovereignty is a matter of belief" recalls Butler's $(1990,179)$ well-known description of gender as "a performative accomplishment which the mundane social audience, including the 
actors themselves, come to believe and to perform in the mode of belief." Moreover, the statement, "If you believe you're sovereign, you're sovereign," in response to the caller's sceptical, even angry question already implies that Turkish Cypriots are suffering from a failure of imagination. But why had Turkish Cypriots' imaginations begun to fail them at this particular moment?

After all, unrecognized or de facto states are by definition states that the rest of the world says should not exist. From their inception, they find themselves subject to international condemnation and hemmed in by embargoes and isolations. They are states "in practice" as opposed to the de jure state, the state "in law." The invocation of practice acknowledges that such entities have all the institutions of governance, allowing them to hold elections and censuses, control their borders, provide health care and social security, and issue identity cards and passports (Caspersen 2011; Harvey and Stansfield 2011; Isachenko 2012; McConnell 2016). Believers in what is usually called the declaratory view of state sovereignty, such as Denktaş, would argue that something that looks and acts like a state is obviously a state. Yet proponents of the constitutive view of sovereignty counter that no matter how much one may perform stateness, one needs an audience to see and recognize the performance as such (see also Rutherford 2012). If "international society participates in the social construction of sovereign states" (Biersteker and Weber 1996, 6), it is because they see and applaud such performances rather than turning their backs on them.

By the time of the television program with the former president, Turkish Cypriots had already lived for close to four decades with their audiences' rejection of their performance and claims of their "quasi-ness." The TRNC's "parent state," the one from which it broke away, had been established in 1960 with a power-sharing constitution between a Greek-speaking, Greek Orthodox majority and a Turkish-speaking, nominally Muslim minority. Three years later, that arrangement broke down into intercommunal violence, and the Turkish-speaking minority retreated into armed enclaves, where they remained for almost a decade (Bryant and Hatay 2011). In 1974, a Greek-sponsored coup against Cyprus's president brought Turkey's military intervention, the immediate effect of which was an ethnic cleansing of the north and the establishment of a Turkish Cypriot state there. Turkish Cypriot state-builders initially named that new entity the Turkish Federated State of Cyprus, anticipating the bizonal federation that they aimed to build with what had become a de facto Greek Cypriot state in the island's south (see Bryant and Hatay 2020). 
Yet after almost a decade of failed negotiations, the Turkish Cypriot legislature declared the "sovereign" TRNC in November 1983. The United Nations and other international bodies immediately condemned this move, and the only state that dared recognize it was the Republic of Turkey, which also supported it militarily and financially. Officially one may only use the name "Turkish Republic of Northern Cyprus" in quotation marks, while calling the boundary that defines that state a border could induce an international brouhaha. It becomes instead a so-called border, a "border," or a ceasefire line.

Although de facto states multiplied in the early 1990s following the breakup of the Soviet Union (e.g., Pegg 1998; Meadwell 1999; Kolstø 2000; Cornell 2002), the TRNC remains one of two states - the other being Taiwan (Friedman 2015) - that have shown the greatest longevity as de facto entities. Nevertheless, today its citizens commonly believe that, as one of many recent newspaper articles phrased it, "a state called the TRNC never existed and never will." Or, as a small business owner I interviewed remarked, “There's no state here, there's an administration." Today, expressions of skepticism about sovereignty are so common that to assert belief in the sovereignty of the TRNC may earn you the label kafatasçı, the Turkish word for phrenologist, indicating both nationalism bordering on racism and belief in something debunked.

Elsewhere, a coauthor and I discuss the contradictions of life in unrecognized states as a consequence of what we call "the paradox of the de facto" (Bryant and Hatay 2020). The paradox is that calling something "de facto" clearly points to facts on the ground that we perceive as undeniably real, even as it denies their reality. Moreover, we see the way that the real persistently raises its head in the apparent compulsion to label everything about such states "de facto": not only do they have de facto sovereignty and de facto passports but also de facto police, de facto judiciaries, de facto civil servants, de facto politicians, and of course de facto citizens. The parent states from which these entities broke away invariably take this labeling a step further, officially calling them "pseudo-states" in an attempt to deny their reality altogether. This also turns all the institutions I just named into pseudo-entities: pseudo-police, pseudo-courts, pseudo-passports.

Of course, all these attempts to deny something while at the same time acknowledging it as "real" produce a sense of absurdity in everyday life, one often infused with humor. For instance, after the opening of the checkpoints in 2003, Turkish Cypriots would often tease their Greek Cypriot friends that they should come more often to eat and drink in the north, because they could not gain weight from pseudo-food and pseudo-alcohol. And I have often heard Greek Cypriots joke 
with Turkish Cypriot friends about having their own pseudo-state, in reference to corruption and incompetence rampant in the island's south (see also Ioannou 2020, 64).

In its more serious guise, however, the pseudo emphasizes falseness and pretending to be something one is not. The de facto, on the other hand, simultaneously acknowledges a "fact on the ground" and denies it (Bryant and Hatay 2020, 6-7). The de facto, then, points to foreclosure, or to the ways that certain "realities" - certain political forms and possibilities — are rendered impossible by the hegemonic norms of the international community. This foreclosure is graphically inscribed through the quotation marks that circumscribe de facto citizens' lives. The quotation marks hand gesture encapsulates the simultaneous acknowledgment and denial that defines the de facto, even as it elides the de facto with the pseudo. So rather than saying "a de facto state" or "a pseudo-state," one can say (with hand gestures) a "state." Rather than the TRNC, one has the "TRNC."

This tendency to emphasize the factitious by using quotation marks is something that Susan Sontag, in an early essay, had described as being at the heart of camp. "Camp," she remarks, "sees everything in quotation marks. It's not a lamp, but a 'lamp'; not a woman, but a 'woman”" (Sontag 1999, 56). For the “camp sensibility," as she calls it, quotation marks create a distancing, calling attention to "Being-as-Playing-a-Role" (Sontag 1999). In our case, the very serious intent of the pseudo-fying discourse is of course to cast the made-up state as "make-believe" or "quasi." And yet as the parodic uses of that discourse above show, these attempts to stamp the de facto state as factitious instead often end up highlighting its "reality." Putting pseudo-state and pseudo-food in the same sentence as things that are equally (un)real performs what Butler $(1990,177)$ refers to as "parodic displacement," where "laughter emerges in the realization all along that the original was derived" (Butler 1990, 176). Certainly, when "passports," "police cars," and much of everyday life are surrounded by quotation marks in a proliferation of pseudo-fying, this creates an atmosphere in which "subversive confusions can be fostered" (Butler 1990, 177).

In this sense, even Denktaş's reply to the agitated caller might be seen as campy, in that, like Butler's primary example of drag, it foregrounds the constructedness and performativity of what the caller took to be essence. The former president suggests that the state is always "made up" in the dual sense of being invented ("sovereignty is a matter of belief") and put on, performed. Indeed, Denktaş showed again and again that he was capable of such a reading, being a British-trained barrister who surrounded himself with other lawyers who knew inter- 
national law and were prepared to demonstrate the arbitary and politicized way in which recognition is granted in the "international community." When Turkish Cypriot politicians voted to declare the "sovereign" TRNC in 1983, Denktaş went to the UN Security Council to defend this move, remarking, "You say that you consider the Turkish Republic of Northern Cyprus invalid. You considered China nonexistent for thirty years, Eastern Germany nonexistent for twenty-five years. It doesn't matter. They are here with us, and I greet them with respect." ${ }^{6}$ In other words, in refusing to recognize the TRNC, he asserted, the UN was simply emphasizing the arbitrary and made-up way in which any state becomes one.

Denktaş, then, while always a firm believer in the state, was also savvy enough to know that the state is not an essence but a performance. This seems, in turn, to point to the fundamental impossibility of "being a state and/or sovereignty" (Weber 1998, 92; see also Butler 1990, 18-19), and therefore to be in line with recent anthropological literature that uses exceptional cases to examine the "made-up" nature of the state as such (see, especially, Navaro-Yashin 2012; McConnell 2016).

Yet this is not all it points to, for if the example tells us that the real is always already fake, that is, made up, it also simultaneously tells us that the fake is always already real, that is, a performance. We will return to this "double inversion," as Esther Newton (1972) terms it, in the final section. For now, we may note that Butler (1997b) explored at length this relation of fake and real in The Psychic Life of Power, where she observed that the focus in her earlier writings on how drag reveals gender as an imitation did not suffice. "However attractive this formulation may have seemed," she notes, "it didn't address the question of how certain forms of disavowal and repudiation come to organize the performance of gender" (Butler 1997b, 145).

Foreclosure is the term that Butler uses to describe this, structuring performance through the impossibility of certain desires, the anticipatory curtailing of which she calls a preemptive loss. Applied to the case at hand, we can see how Butler's description of what foreclosure implies would prove just as relevant to citizens of a foreclosed state. If sovereignty "is from the start out of the question, then it cannot happen, and if it does, it certainly did not. If it does, it happens only under the official sign of its prohibition and disavowal" (Butler 1997b, 139). We see the official sign of such prohibition and disavowal in the ways that de facto states are most commonly described as "pirates," and therefore outlaws, or "puppets" of another state, making them not "real" ones themselves. "They are 
stigmatised," and "by their very nature, sit apart from the established international order" (Ker-Lindsay 2018, 362). ${ }^{7}$

In the postmillennial era, transnational entities have begun to engage with this de facto entity, but only because of Turkish Cypriots' new willingness to disavow their state as a "state." As we will see in the next section, such performances in the mode of disbelief structure the unbecoming state. The unbecoming emerges when confronted with something both normatively impossible and ineluctable: a "real" that must be "pseudo." The state that is performed "is constituted by a set of disavowed attachments" that "carry the mark of impossibility with them, performing, as it were, as the impossible within the possible" (Butler 1997b, 147). The performances of disavowal also render this entity unbecoming in the sense of unfit or unsuitable, in this case for the international order. Indeed, as we will see, these performances of disavowal have created the more general sense that citizens of north Cyprus are actually faking it, and that their sovereignty is as real as Burger City and Pizza Hat.

\section{ENGAGEMENT AND OTHER PARODIES}

If one searches today on Google Maps for the Turkish Republic of Northern Cyprus, not only does it produce a result but it shows the entity in the south only as "Cyprus" rather than as the "Republic of Cyprus." When sharing this discovery on social media, one retired Turkish Cypriot woman, a former teacher, commented, "Good morning, lovely people. Google loves you! It turns out. . . . We exist!" The comment facetiously reflects both the preemptive loss with which Turkish Cypriots tend to anticipate the denial of their stateness and the surprise at the unexpected and arbitrary ways in which the rest of the world may sometimes acknowledge it.

Such surprise emerges because even if Google Maps seems to accept their sovereignty claims, the UN and other international bodies persistently tell them that the space indicated by Google Maps cannot and should not exist. Indeed, most citizens of this de facto entity have been conditioned by decades of isolation to the knowledge that the world pretends not to see them. After all, from 1974 to 2003, they lived under embargo and isolation, hindering their ability to travel and trade. International actors turned their backs, overlooked, and refused to engage in the forms of interaction that produce the audiences for whom one must perform.

During that period, Turkish Cypriots' single audience consisted of Turkey, the only state that recognized them. ${ }^{8}$ Turkey recognizes TRNC passports, gives special scholarships to Turkish Cypriot youth, and is the one state with which 
they sign protocols. It has been and remains the only state that welcomes Turkish Cypriot leaders as heads of state, and it remains the first foreign state on which newly elected Turkish leaders call. Other governments have tended to pretend that the TRNC does not exist. Although Turkish Cypriots were equal partners in the RoC's constitution, international bodies avoided consulting them, to the extent that in 1997 the EU began an accession process with the Greek Cypriot-controlled government in the south that excluded the wishes of the RoC's Turkish Cypriot partners.

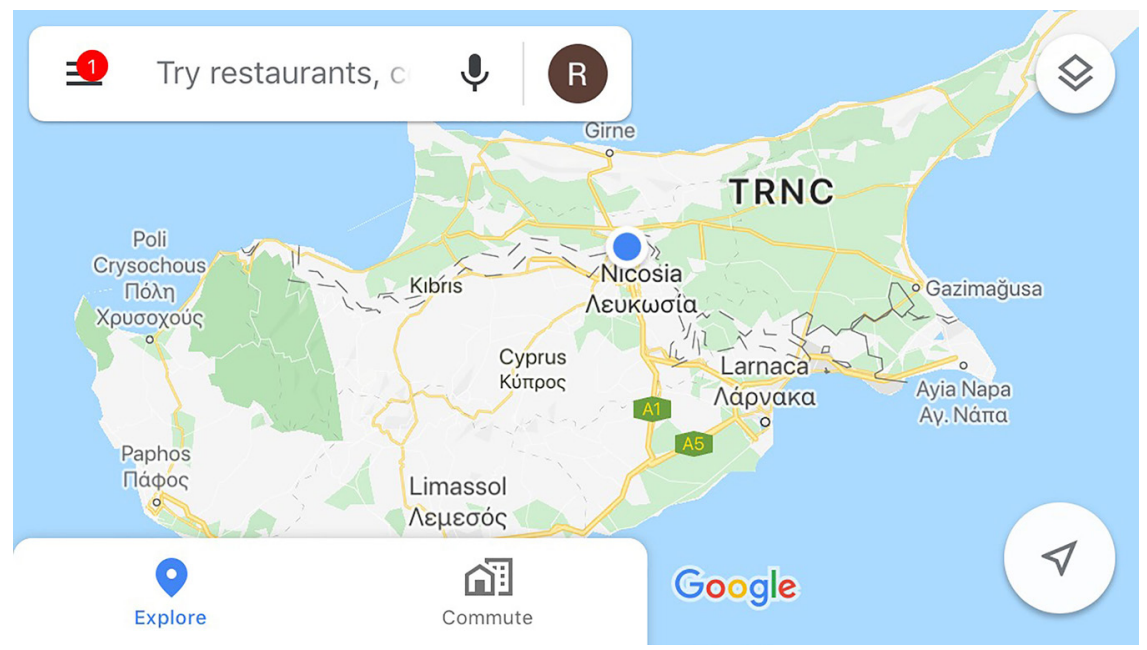

Figure 7. Google Maps and the sovereign “real” Map data: @2019 Google.

The EU's acceptance of the RoC, however, did lead to a political change in the north, when in 2002 Turkish Cypriots embraced a UN reunification plan to create a federal Cyprus in advance of the RoC's 2004 EU accession. Turkish Cypriots demonstrated for months, even against nationalist leaders such as Denktaş, leading hard-line politicians to ease movement restrictions on the island and to open the checkpoints for people to cross the "border." Even though Greek Cypriots would go on to reject the UN plan at referendum in 2004 (see Bryant 2010), Turkish Cypriots' overwhelming backing of it led to increased engagement with the international community. This period also saw a change of government in Turkey, the north's patron state, bringing global capital to the island in the form of hotel chains and cafés, cars and clothing. Suddenly, Turkish Cypriots had a wealth of audiences in the form of EU bureaucrats and transnational institutions for whom they needed to perform. 
Unexpectedly, though, they found that the script had changed. For much of the previous three decades, they had been cast in the contradictory role of either pirates who had made off with part of a recognized state or as puppets of their patron state, Turkey. ${ }^{9}$ What unites these two otherwise entirely opposite roles is that both puppets and pirates display the wrong kind of will: puppets have no will, while pirates have too much of it. Sara Ahmed $(2014,79)$ describes such a "queer will" as one unable to will what it should be willing to will-in other words, one that stubbornly clings to a foreclosed desire. The mass demonstrations in support of the UN reunification plan, on the other hand, had shown the right kind of will, a will to forego what the rest of the world perceived as either secessionism or occupation, instead displaying a political will for reunification.

Among other things, this will had been one to EU citizenship. After the 2003 easing of movement restrictions, almost 100,000 Turkish Cypriots crossed to the south to claim their soon-to-be-EU passports. With those in their pockets, however, it became much more difficult to know what they were to will, or how they were to perform. After all, as EU citizens, it made little sense to perform a state whose existence the EU denies. The EU accepts the RoC's claims of sovereignty over the whole island, meaning that after the RoC's admission to the EU, the north officially became exceptional EU territory in which the acquis communautaire, or body of EU law, is suspended. Official EU maps label the north "areas outside government control," while judgments in the European Court of Human Rights have called the administration of north Cyprus Turkey's "subordinate authority" for purposes of international law. In everyday life, then, as one struggling farmer commented to me, "I may be treated as an EU citizen if I leave the island and go to, say, Amsterdam, but I can't receive the benefits of EU citizenship in my own home."

In everyday performances in which citizens enact the state, however, this change of setting clearly resulted in confusion regarding the script. That confusion may be seen in the ways that today Turkish Cypriots often mock the name of their state, use the quotation marks hand gesture when referring to it, or simply cannot pronounce it altogether. For instance, Turkish Cypriot sports teams are unable to play international matches, and in recent years one of the only opportunities to do so was offered by CONIFA (Confederation of Independent Football Associations), the league of unrecognized states and peoples. In a match against Abkhazia, I witnessed Turkish Cypriots struggling to figure out what to shout in support of their team. There were some sputters of "KKTC" (TRNC) or "Kuzey Kibris" (North 
Cyprus), before fans who seemed to choke on these names finally settled on "bizim takım” (our team).

This failure of naming (Butler 1997a; vom Bruck and Bodenhorn 2006) is only one instance of the ways that increased engagement with the de facto state in the post-2003 era has produced a disavowal of the stateness of their state. In the post-referendum period, the EU's engagement with Turkish Cypriots and with the territory of the north began to include financial support for infrastructural and other development in rather hopeful anticipation of the island's ultimate reunification. Despite their engagement with the EU as its citizens, however, Turkish Cypriots remain unable to trade freely or to have relations with that supranational body without going through the administration of the RoC. Today, for instance, the EU supports restoration and infrastructural projects in the north, but only by gaining the approval of the RoC as the north's sovereign power. In other words, while the EU and international agencies such as the UNDP (United Nations Development Programme) are willing to put their money into the north, and to do so cooperate with state agencies there, such international agencies undertake this cooperation only with a "state" (in quotation marks), in other words as the "areas outside government control."

This mode of interaction falls under a strategy that one EU diplomat has termed "engagement without recognition" (see also Caspersen 2018; de Waal 2018; Kyris 2018). ${ }^{10}$ It describes a form of interaction quickly becoming the primary way in which supranational entities such as the EU, as well as global big business, interact with such state-like entities. Some scholars have already noted that the effect of international censure and sanctions may undermine their aim, in that sanctions already acknowledge a state that must be acted against, hence giving such states "a sovereign shape, if not a sovereign status" (White 2009, 154). In the case of "engagement without recognition," the engagement has the paradoxical effect of strengthening the very political and economic institutions that are refused recognition.

At the same time, such institutions engage with the state only as a "state," with its ministers as "ministers," its politicians as "politicians." Those who wish to benefit from this new political and economic engagement do so only through disavowal, for instance by allowing their profession and titles to be put in quotations marks or not used at all. Engagement is possible only through the quotation marks hand gesture that suggests disbelief in the "state's" sovereignty. This kind of engagement in the north thus only emerged when, beginning in 2003, Turkish Cypriots began to disavow secessionist aspirations, call en masse for federation, and 
became satisfied with, for instance, calling their entity "north Cyprus" rather than "TRNC" in tourism advertising. The retired teacher's surprise at Google Maps' use of TRNC to label north Cyprus is only one example of Turkish Cypriots' implicit knowledge that certain options are foreclosed for them.

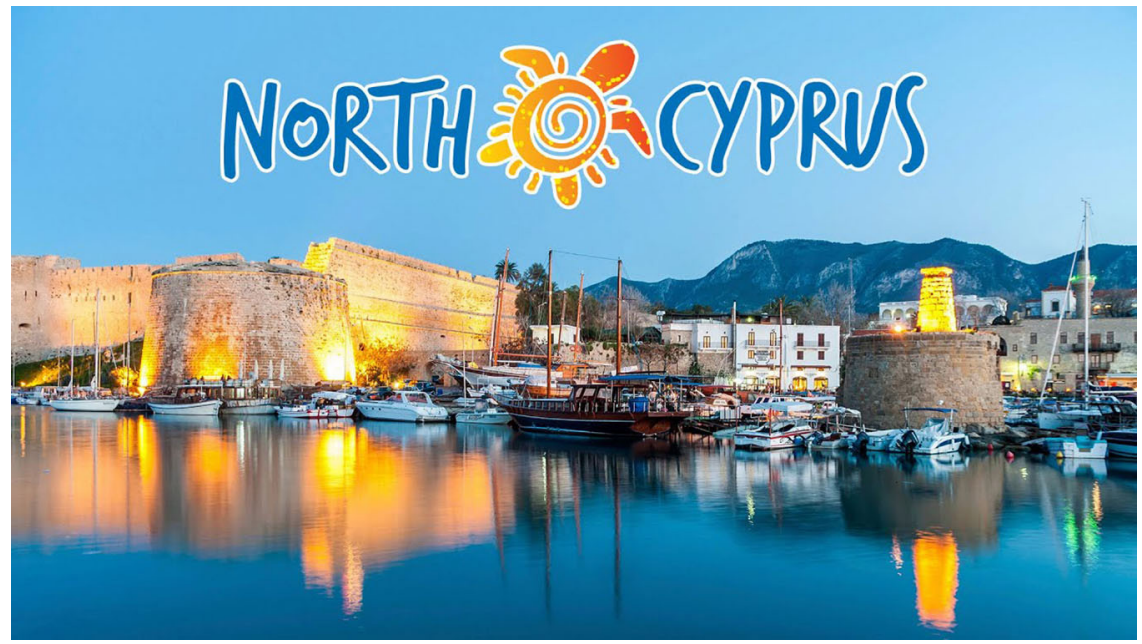

Figure 8. Touristic disavowal. Photo by Rebecca Bryant.

The contradictions that emerge from this recognition-that-is-not-one have become especially clear in Turkish Cypriots' post-2003 interactions with the RoC, the entity most interested in making sure that their state remains a "state." Before 2003, the RoC had not instituted a border regime at crossing points to the island's north. As a result, when Turkish Cypriot authorities decided to open the checkpoints in that year, the Republic of Cyprus had to enact border practices for a border that it did not recognize. In the immediate term, this meant acknowledging the identity cards of Turkish Cypriots that had been issued by the TRNC. The information on these cards was checked against computer records to ensure that the persons crossing were in fact Turkish Cypriots and not Turkish nationals who had acquired TRNC “citizenship.” Once they had acquired RoC identity cards, most Turkish Cypriots began to present them when crossing. When asked, a number of Turkish Cypriots told me that these identity cards "make things easier," and "without them, the Greek Cypriots might cause trouble."11

Yet interestingly, Greek Cypriot police at the checkpoints continue reluctantly to accept TRNC identity cards when Turkish Cypriots present them for crossing — although the police will often ask if the Turkish Cypriots do not have 
RoC identity cards. Indeed, some Turkish Cypriots I know who carry RoC identity cards often present their TRNC identity cards when crossing as a political statement and to check the reaction of the Greek Cypriot border police. Another incident I experienced at the border indicates that other TRNC-issued documents are similarly "acknowledged."

Today, because Cyprus in its entirety is technically EU territory, EU citizens are able to enter the island through the otherwise illegal ports in the north and pass to the south. Third-country nationals from outside the EU, however, must enter through the south for the RoC to consider their entry legal. For this reason, several years ago the U.S. embassy website gave the advice that any U.S. citizen living "outside the areas under government control" should apply for RoC residency to remain more than three months. At the time, as a U.S. passport holder living and conducting research in the island's north, I wanted to make my presence there legal from the RoC perspective and so went to the immigration office to apply for a residence permit.

The office was quite crowded that day, mostly with laborers from South Asia, Russia, and other non-EU Eastern European states. I managed to corner one particularly harried immigration officer to ask her how I might apply for a residence permit while living in the north. Her eyes widened in surprise, and she asked me to repeat the question. "Why would you want to do that?" she asked. I replied, "I want to be able to enter and exit through the south without worrying about visas." The officer's brow furrowed, and she thought for a moment. "Just use Ercan!" she concluded.

Ercan is the "illegal" airport in the island's north, the airport through which EU nationals may now enter but which is technically forbidden to holders of other passports. I would later get the same response from three other officers in the immigration bureau: "Just use Ercan!" they all said.

Not long after this, my Turkish Cypriot partner and I married, and I received an identity card from the unrecognized TRNC. This identity card entitles me to residence in the north, and to travel between north Cyprus and Turkey, but apart from that it is the identity document of an unrecognized state and so has no currency. This would presumably hold especially true for the RoC, which has the greatest stake in delegitimizing the regime in the island's north. Yet interestingly, the border regime that emerged after 2003 not only allows Turkish Cypriots to cross using these cards but also allows their spouses and children to do so.

At one point I had dropped off my U.S. passport at the embassy to have pages added, but during that same period needed to cross to the south. My partner told 
me to try out the TRNC identity card to see if the guards would allow me across. They asked to see my marriage certificate, and I produced one from the United States, where we had gotten married a second time in an effort to make the union more "legal." "What's this?" asked the puzzled guard behind the glass. She turned it around as though the script was illegible, then showed it to her supervisor. "You don't have a marriage certificate from Cyprus?" she asked. I did have such a certificate, but it had been issued by the TRNC, the entity whose administration and documentation the RoC consider illegal. To the guard's apparent relief, I produced the document. She tossed the worthless U.S. marriage certificate across the desk and proceeded to enter my information in the RoC's extensive computerized database. Handing the documents back, she reassured me, "Now you can cross whenever you want using that card."

Although the policewoman accepted the card and preferred the TRNC marriage certificate to the U.S. one, and although the immigration officers repeatedly suggested that I should simply "use Ercan," this acknowledgment is also arbitrary and dismissive, thereby suggestive of a favor. The immigration officers did not suggest using Ercan because they recognized it; they suggested using it because they could not be bothered to deal with yet another ambiguous case. At the same time, it was easier for them simply to accept the TRNC documents, which were familiar to them and contained information such as my husband's name, his place of birth, and his parents' names and places of birth, allowing the officer to confirm that he was a "real" Cypriot.

Given the authorities' use of those documents, it might be tempting to conclude that the pseudo-state rhetoric is itself fake, something put on for international audiences even as they know that a working state in the island's north really exists. The effect, however, is to reinforce the RoC's authority as the "real" state, and its representatives as the ones to decide, sometimes arbitrarily, which documents to accept and which applications to process. This situation often leaves Turkish Cypriots and their families scrambling for other documents — or as in my case, attempting to preempt accusations of illegality by getting married twice.

My act of getting married a second time is what Butler (1997b, 23-24) meant when she referred to foreclosure as a "preemptive loss" that "becomes the condition of possibility for social existence." One acts on the preemptive assumption that TRNC documents cannot have meaning and should not exist, and one anticipates refusal. Surprise at the documents' currency is its own form of disavowal. For Butler, this encounter with the limits of the subject's power induces melancholia. Turkish Cypriots themselves have begun to call it "learned helpless- 
ness" (ögrenilmiş çaresizlik), a psychological term used to refer to the passiveness produced in subjects repeatedly subjected to aversive stimuli.

However, like the demoralization of Serbian workers who perform jobs that they see as pointless, this "was not altogether a gloomy condition" (Rajković 2018, 48 ) but entails a self-mocking irony so pervasive that even retired schoolteachers can perform it. The social media post quoted above exclaiming, "It turns out. . . We exist!" contains both the melancholic longing of foreclosure and the mocking attitude that points to the arbitrariness of others' recognition. It also implicitly points to a shoulder-shrugging puzzlement that even as Turkish Cypriots disavow their secessionist aspirations, call for federation, and may be perfectly fine calling their own state "north Cyprus" rather than the TRNC, Google Maps shows us where this place is in the world. Precisely this paradox of existing only to the extent that one does not exist leaves many Turkish Cypriots with a sense of failure both deeply troubling and a prime source of camp.

\section{"SO CAMP AS KEEPS US GOING"}

Another aspect of Turkish Cypriots' political existence visible on Google Maps is the so-called TRNC's so-called flag, painted on the Five Finger Mountains the size of four football fields. Google's satellite imagery shows it clearly, and some say that it is visible from space. It is certainly within clear view from south of the cease-fire line, and indeed appears to have been intentionally positioned to taunt Greek Cypriots from almost any position in south Nicosia. From when it was first painted until 2001, it only taunted during the day. Yet right after the turn of the millennium some enthusiastic Turkish Cypriot nationalists formed a committee and raised money to light the flag at night. ${ }^{12}$ Since 2003, a light show illuminates it every evening, the flag disappearing into darkness and then gradually reappearing, first as the star and crescent of the Turkish flag, and then with the horizontal lines at the top and bottom that distinguish it as the Turkish Cypriot flag.

For many Turkish Cypriots, the giant flag has become what a friend called "an expression of our nonrecognition complex," referring to the way in which it responds to the denials of the TRNC's existence. It does this, though, through a poke in the eye of the international community, defying other states' refusal to see them. Its brightly lit emblem says, "We are here," asserting a fact on the ground that to date no other state has tried to alter. Yet the flag insists too much, and in that insistence, it persistently calls attention to the paradox of the de facto- of both presence and its denial. When our friend invoked it as a symbol of a nonrec- 
ognition complex, he suggested that it "fails even as it succeeds and succeeds even as it fails" (Bryant and Hatay 2020, 158).

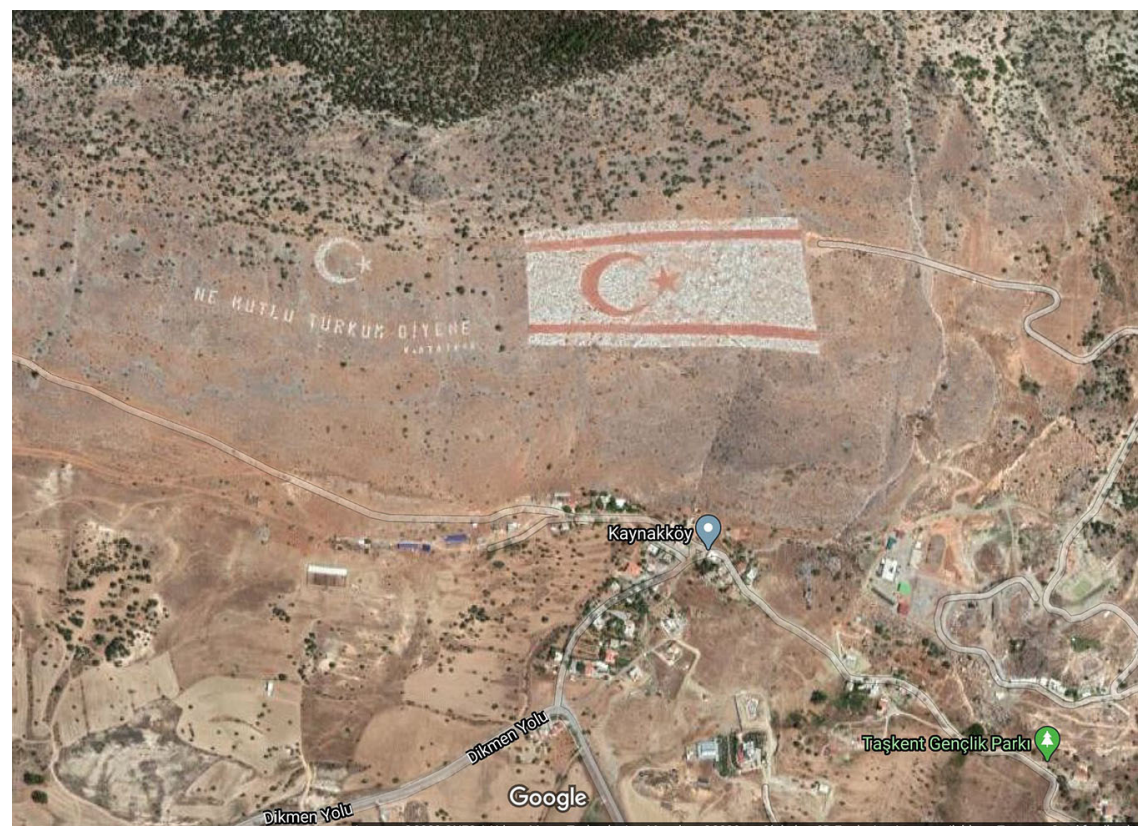

Figure 9. Google also loves the TRNC flag. Map data: Google, Maxar Technologies.

The flag is clearly what Cynthia Weber (1999), in her witty Faking It, would have referred to as a "fantasy phallus," a strapped-on dildo that points to a phallic lack. Such phallic metaphors are not far from many people's minds, as when one commentator on social media suggested that it is "like a dog urinating on a lamp post to identify its territory." Such a metaphor also suggests insecurity and a sense of failure. As another commentator, writing in the south's main English-language newspaper, claimed, the flag "is just a protest flag that asserts a state without inspiring its realisation and fails as a flag" (Riza 2015).

Of course, as the metaphor of a urinating dog suggests, the flag's size and in-your-face insistence make it seem a parody of itself, a sign of faking the state. And yet at one and the same time the flag does successfully assert sovereignty by challenging others to remove it. In other words, the flag constitutes a form of drag, a "flag" imitating a flag. Yet through its unintentional parody, the flag accomplishes what Esther Newton $(1972,103)$ calls a "double inversion." On the one hand, the ridiculous size of the flag points to a "state" (or a pseudo-state) that is still, in its essence, real enough to put the flag on the mountain. This is the kind of 
"performative illusion" that Sasha Newell $(2013,142)$ points to when he notes that Ivoirian bluffeurs' display of brands "is at once known to be false and yet respected as having real and potent value." On the other hand, and simultaneously, the force symbolized by the flag is eviscerated by the knowledge that it is only a symbol of a non-recognition complex, that is, it constitutes in its "essence" a pseudo-flag.

Given that the flag already performs such a parodic displacement, then, it may seem unnecessary to even bother to parody it, and yet it has become a prime source of camp. A couple of years after the flag's illumination, one friend decided to capture the light show on film, creating an ironic, fifty-second video set to ska music. The filmmaker asks in the YouTube video's caption, "Is the world's largest flag a symbol of our existence, or of our nonexistence?" In the video, the flag lights up against a darkened city, demonstrating how it is "illuminated at night to show off despite frequent electricity cuts." The caption concludes, "Here we have the TRNC's tragicomic story." ${ }^{\prime 3}$ The tragicomedy resides in the fact that a state which cannot even keep its electricity working proclaims itself with the world's largest flag.

While the flag may represent aspirations to sovereignty for some die-hard believers, many Turkish Cypriots consider it a flag in drag. And though the flag itself may seem campy, seeing it that way depends on what Sontag calls a "camp sensibility." The video demonstrates such a sensibility, and in doing so creates the "context and reception in which subversive confusions can be fostered" (Butler 1990, 177). At the same time it does something else by calling attention to the affective aspect of living with a flag in drag, an in-your-face symbol of a non-recognition complex. We see from the retired teacher's ironic proclamation of existence, or from the videomaker's angst-filled question about such existence, an affect in relation to foreclosure that Butler summarized as melancholia but that we may more specifically think of as learned helplessness or demoralization. Certainly, along with melancholia, it also entails what Ivan Rajković $(2018,48)$ describes as "a certain stance of abandon and nonchalance," or as his interlocutor Vladimir vividly put it, "If you're being fucked, then at least relax."

In this sense, camping what already seems a parody becomes what Newton $(1972,34)$ called a "strategy for a situation," in other words, "a peculiarly 'gay' way to handle the burden of stigma" (Cleto 1999, 89). Here, I will substitute unbecoming for gay, as a more general way of describing desires that are always already foreclosed. Moreover, unbecoming calls attention to the ways that foreclosure creates performances, like the flag in drag, that are also unbecoming in the other senses of the word: unattractive, unsightly, and unsuitable - in this case, for the 


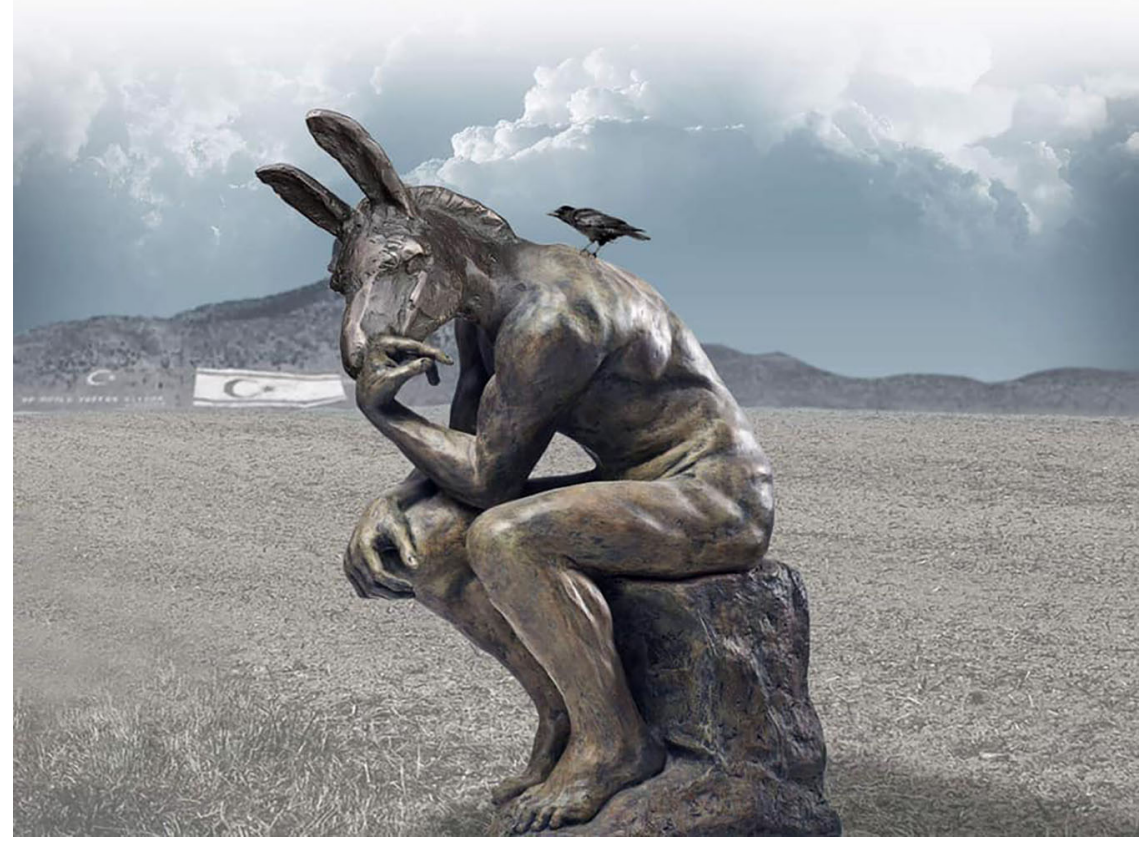

Figure 10. The donkey as symbol of the melancholic Cypriot. Courtesy of Senih Çavuşoğlu.

international community. As a "strategy for a situation," the parody and campiness that currently pervade Turkish Cypriots' approaches to their state appear as "the community-building survivalist dealing with the signs of a stigmatised . . . identity" (Cleto 1999, 90; emphasis original)—or in this case, a stigmatized "state.” As Richard Dyer $(2002,49)$ put it, "It's being so camp as keeps us going."

\section{CONCLUSION: Faking It Is Not What It Seems}

In December 2019, Burger King joined a growing number of "real” fast-food franchises to open in north Cyprus. Yet in contrast to, say, Popeyes or Gloria Jean's, Burger King had actually had a presence in the north for the past twenty years, but under the name Burger City. Rather than selling fake products disguised as real, these were "real" products disguised as fake. While locations in the north actually formed part of the Burger King chain, they operated under the name Burger City to appear fake and thus evade the problem of non-recognition - in other words, to avoid Greek Cypriot protests against opening a real chain in the north.

Rather than a simulation, then, Burger City was a dissimulation, reflecting the useful distinction that Jean Baudrillard $(1994,3)$ draws between the two: "To dissimulate is to feign not to have what one has. To simulate is to feign to have 
what one hasn't." Cynthia Weber $(1999,108)$ describes such dissimulation as masquerading, "a strategy whereby something is added (clothes or a demeanor, for example) not to conceal a lack, but rather to create the appearance of one." This also makes it seem that we might use such masquerade as a metaphor for the de facto state, which appears fake in order to continue as "real."

Yet even with the fast-food example we can also see how the "gap between the play and the real" (Badiou 2007, 48) produces both "an unstable slippage between the constructed surface image of the thing . . . and the inescapable but invisible realness of the object" (Newell 2013, 151). We assume some authenticity to Clark's shoes or Burger King hamburgers. Yet when Burger City recently became a real Burger King, many people expressed disappointment at the fact that the burgers stayed the same. Similarly, a proliferation of the pseudo-state rhetoric may also be explained by the ways in which pseudo-ness has become an appropriate way of describing the failures of the "real."

Yet there is something more in this unstable slippage. Examples such as Google Maps and the giant flag show that the de facto state is not so much a copy of a state — a "state" — as it is a disavowed parody of a "state" — a "pseudo-state." Just as one pretends that Burger City is a fake even though everything about it - including the taste of the burgers - is the same as the original, and one does this to circumvent the impediment of non-recognition, so pretending that the TRNC is a "state" allows one to avoid appearing to want recognition. For citizens, however, the effect becomes a ritualized disavowal that turns desire into a preemptive loss. The unbecoming state is one in which the blurring of fake and real does not result in some performative freedom, but rather in a demoralization whose most appropriate response is camp.

Yet like drag performance, the effect on the audience is often a parodic displacement that calls attention to the made-up nature of any state, thus making this one appear as real as any other. For instance, one political scientist friend recently commented to me with surprise that in interviews that he had done with EU bureaucrats and Greek Cypriot politicians many often seemed very comfortable these days talking about the north as the TRNC — the name they're not supposed to use, or only use in quotation marks. While present-day diplomats and EU bureaucrats are required to use "TRNC" with the quotation marks hand gesture, like the salesgirl, they tend to do so with a conspiratorial smile. The wink and laugh of the EU bureaucrat who puts TRNC in inverted commas or calls it a "pseudo-state" is intended to indicate to the listener, "We don't believe in all this 'pseudo' business, either, but we have to play by the rules." And so we see that not only for salesgirls 
and discerning shoppers, but even for diplomats and political scientists, faking it may not always be what it seems.

\begin{abstract}
A growing ethnographic literature demonstrates the mundane practices through which both the state and sovereignty are performed. This article asks at what point such performances succeed or where they may fail, even for those enacting them. The article builds on long-term research in an unrecognized state, the "Turkish Republic of Northern Cyprus," which is often called a pirate or pseudo-state and which has undergone several decades of international isolations. Since the early 2000s, however, Turkish Cypriots have experienced the closer integration of their "state" into the global economy and transnational institutions. This has resulted in international engagement with their "state" that has made it appear more "real," even as, paradoxically, citizens have developed their own pervasive discourse of pseudo-ness. The article uses examples of engagement with the unrecognized entity to show how, in the context of globalization, citizens learn, in their daily lives, to perform their state as a "state," persistently calling attention to the made-up nature of their sovereignty claims. The article develops the concept of the unbecoming to refer to entities that are foreclosed from their inception, as well as the unsuitable or unfitting form that such entities acquire when certain desires are always already impossible. [sovereignty; de facto; performance; performativity; camp; Cyprus]
\end{abstract}

\title{
ÖZET
}

Her geçen gün artan sayıda etnografik literatür, devlet ve egemenliğin günlük pratikler aracılığılla gerçekleştiğini göstermektedir. Bu çalışma, bu tip performansların hangi noktada başarılı olup hangi noktada başarısız olabildiğini sorgulamaktadır. Bu makale, sık sık korsan veya sahte devlet olarak anılan ve uzun yıllar birçok izolasyona tabii tutulmuş, tanınmamış bir devlet olan "Kuzey Kıbrıs Türk Cumhuriyeti”nde yapılmış uzun dönemli bir araştırmayı zemin olarak almaktadır. Ancak 2000'li yılların başından beri Kıbrıslı Türkler “devlet”lerinin küresel ekonomi ve transnasyonal kurumlarla daha yakın bir entegrasyon yaşadığına şahit olmaktadırlar. Bu gelişme, paradoksal bir şekilde vatandaşların yaygın bir halde kendi "uyduruk devlet” söylemlerini geliştirmiş olmalarına rağmen, "devlet”lerinin uluslararası angajmanlara girmesiyle daha "gerçek" bir görüntü yakalamasına neden olmuştur. Bu çalışma, küreselleşme bağlamında tanınmamış bir entite ile kurulan ilişkilerden örnekler vererek, vatandaşların nasıl bir taraftan ısrarla kendi egemenlik iddialarının uyduruk yapısına dikkat çekerken diğer taraftan günlük hayatlarında "devlet"lerini "devlet" olarak icra etmelerini göstermeye çalışacaktır. Bu makale "oluşamayan" tanımıla, bazı arzular her zaman ve hali hazırda imkansız olmasına rağmen bazı entitelerin başlangıçtan mümkün olamayan, ayrıca uygunsuz, uymayan bir yapıya 
sahip olduklarını kastetmektedir. [egemenlik; de facto; performans; performatiflik; camp; Kıbris]

\section{NOTES}

Acknowledgments This essay emerged from research on de facto states and globalization in the context of a four-year Norwegian Research Council-funded project titled "Imagined Sovereignties," led by the Peace Research Institute Oslo, 2012-2016. I thank Åshild Kolås, that project's lead, for her support and patience. I am very grateful to the participants in the 2016 conference titled "The Everyday Lives of Sovereignty," which I organized as part of the "Imagined Sovereignties" project. In particular, I thank Madeleine Reeves and Lisa Wedeen for their continued and always perceptive engagement. Many persons have listened to or read versions of this article along the way, and among those I particularly want to thank David Henig, Nina Caspersen, Thomas de Waal, and Cynthia Weber, as well as four anonymous reviewers for their insightful criticisms.

1. For more on Nicosia's division, see Yiannis Papadakis (2006). On the trading relationships that were severed by the division, see Anita Bakshi (2016).

2. I should note that although this description was accurate at the time of writing, at the time of publication, COVID-19 restrictions had halted casual crossings and shuttered businesses on both sides of the divide. Because of its centrality to trade in the city, my assumption is that the street will regain something like its former traffic once the world returns to some form of "normal."

3. My discussion of faking builds on a growing anthropological literature that addresses the production of "clean fakes" (Reeves 2013) or "truthful fakes" (Bubandt 2009) and the "piracy infrastructure" (Larkin 2004, 190) that makes them possible. Such studies show the ubiquity of piracy, as well as the relationship between counterfeit products and global capitalism (Pang 2008). Much of this literature is concerned with the "instability between appearance and the genuine" (Newell 2013, 138), or the ways that fakes call into question what is authentic. While I address these issues at greater length in a forthcoming book manuscript (Bryant, in progress), my focus here and in a recent coauthored book (Bryant and Hatay 2020) is on the kinds of complex agency that emerge when "faking" the state.

4. While the vast majority of pirated products apparently come from Turkey and counterfeit global brands, there is also the phenomenon in north Cyprus of copying Turkish brands (see also Brandstädter 2009, 130). For instance, the Turkish ice cream chain Mado has a copy in north Cyprus calling itself Mardo. While the "original" also exists in Cyprus, interestingly the copy proves more popular among Cypriots.

5. I refer to popular sovereignty and unbecoming sovereigns here in part to point to the failures of what we might call sovereign agency, or the ability to achieve what one wants when one wants it. See note 7 for more on this point.

6. "Mr. R. R. Denktash Addressing the U.N. Security Council on Nov/1983."

7. At first glance, it appears that the desire being foreclosed is for "real," that is, recognized, state sovereignty. Being a strong believer in state sovereignty himself, this is also likely how Denktaş understood the agitated caller's expressions of disbelief. However, if we look historically at the political aims that have mobilized Turkish Cypriots, what becomes clear - as I argue at length elsewhere (Bryant and Hatay 2020; Bryant 2021; Bryant and Reeves 2021a, 2021b) — is that the TRNC is only the culmination of Turkish Cypriots' decades-long search for what we may summarize as sovereign agency, what the political theorist Patchen Markell (2003) has articulated as an imagined form of effective agency or control in which one will be able to achieve what one wants when one wants it.

In the vernacular, this is often expressed as "being the master in our own country" (kendi memleketimizde efendi olmak), and I show in other work how the desire to be a 
"master" (efendi) is one that has historically united the nationalist right, which has sought international recognition, and the federalist left, which believed such recognition would only be possible through a bizonal federal state with Greek Cypriot partners. In both cases, this has involved having a space of one's own and being recognized as a political equal with the larger Greek Cypriot community. Being an efendi, then, is a vernacular way of expressing what my leftist friends on the island refer to as özne olmak, literally a subject, but used to mean someone with sovereign agency, the ability to be "an independent, self-determining agent" (Markell 2003, 26), that is "capable of agentive agency" (Greenberg 2011, 89).

8. Turkish Cypriots' relationship with Turkey also plays a significant role in citizens' ability to believe in the de facto state, but it is a relationship that I bracket in this article because it is also one that has generally continued within certain well-defined parameters for several decades. Since the 1950s, that relationship has been euphemized in familial terms as one between a "Motherland" and a "Babyland" (Yavru Vatan). I discuss at length elsewhere how this relationship has changed in the period after 2002, when Turkey's current ruling government, the Justice and Development Party, came to power and shifted the relationship to one that many persons I interviewed described as one of a "disciplinary father" and "unruly children" - or as one interviewee put it, "A mother who behaves like a father" (Babalik yapan bir ana) (see Bryant and Yakinthou 2012). For reasons of space, I choose here to focus on TRNC citizens' new transnational and international relationships since 2002, but many of the observations regarding foreclosure are also applicable to the post-2002 Turkey-north Cyprus relationship (see Bryant and Hatay 2020; Bryant, in progress).

9. The "patron state" is a common way of describing a larger state that protects an unrecognized entity, usually giving it financial and military support. While in north Cyprus's case this patron is Turkey, in the case of Abkhazia or South Ossetia it is Russia, and in the case of Nagorno-Karabakh it is Armenia.

10. This is the phrase of Peter Semneby, the EU's special representative for the South Caucasus, as quoted in Neal Ascherson (2010).

11. Because Turkish Cypriots were originally partners in the $1960 \mathrm{RoC}$, even nationalist Turkish Cypriots make reference to the RoC constitution in justifying acquiring the documents of RoC citizenship and hence EU passports.

12. KKTC Beşparmak Dağları Bayrağı Iş̧ılandırma Derneği website, http://www. kktcbayrak.org.

13. sistem83, "KKTC Bayrak/TRNC Flag," YouTube Video, 0:50, January 9, 2007, https:// www.youtube.com/watch?v=AgB_oJ_D4as.

\section{REFERENCES}

Abrams, Philip

1988 "Notes on the Difficulty of Studying the State (1977)." Journal of Historical

Ahmed, Sara Sociology 1, no. 1: 58-89. https://doi.org/10.1111/j.1467-6443.1988.tb00004.x.

2014 Willful Subjects. Durham, N.C.: Duke University Press.

Ascherson, Neal

2010 "Abkhazia and the Caucasus: The West's Choice." Open Democracy, August 6. http://www.opendemocracy.net/neal-ascherson/abkhazia-and-south-caucasuswest $\%$ E2\%80\%99s-choice.

Badiou, Alain

2007 The Century. Cambridge: Polity.

Bakshi, Anita

2016 "Trade and Exchange in Nicosia's Shared Realm: Ermou Street in the 1940s and 1950s." In Post-Ottoman Coexistence: Sharing Space in the Shadow of Conflict, edited by Rebecca Bryant, 107-26. Oxford: Berghahn Books. 
Baudrillard, Jean

1994 Simulacra and Simulation. Translated by Sheila Faria Glaser. Ann Arbor: University of Michigan Press.

Biehl, João, and Peter Locke

2010 "Deleuze and the Anthropology of Becoming." Current Anthropology 51, no. 3: 31751. https://doi.org/10.1086/651466.

Biersteker, Thomas J., and Cynthia Weber, eds.

1996 State Sovereignty as Social Construct. Cambridge: Cambridge University Press.

Bobick, Michael

2017 "Sovereignty and the Vicissitudes of Recognition: Peoplehood and Performance in a De Facto State." PoLAR 40, no. 1: 158-70. https://doi.org/10.1111/plar.12204.

Brandstädter, Susanne

2009 "Fakes: Fraud, Value-Anxiety, and the Politics of Sincerity." In Ethnographies of Moral Reasoning: Living Paradoxes of a Global Age, edited by Karen Sykes, 139-60. New York: Palgrave Macmillan.

Bryant, Rebecca

2010 The Past in Pieces: Belonging in the New Cyprus. Philadelphia: University of Pennsylvania Press.

2021 "Sovereignty in the Skies: An Anthropology of Everyday Aeropolitics." In The Everyday Lives of Sovereignty: Political Imagination beyond the State, edited by Rebecca Bryant and Madeleine Reeves, 19-43. Ithaca, N.Y.: Cornell University Press.

In progress Faking the State: On Pirates, Puppets, and Other Unbecoming Subjects.

Bryant, Rebecca, and Mete Hatay

2011 "Guns and Guitars: Simulating Sovereignty in a State of Siege." American Ethnologist 38, no. 4: 631-49. https://doi.org/10.1111/j.1548-1425.2011.01327.x.

2020 Sovereignty Suspended: Building the So-Called State. Philadelphia: University of Pennsylvania Press.

Bryant, Rebecca, and Daniel M. Knight

2019 The Anthropology of the Future. Cambridge: Cambridge University Press.

Bryant, Rebecca, and Madeleine Reeves, eds.

2021a The Everyday Lives of Sovereignty: Political Imagination beyond the State. Ithaca, N.Y.: Cornell University Press.

2021b "Introduction: Sovereign Agency and State Desire." In The Everyday Lives of Sovereignty: Political Imagination beyond the State, 1-18. Ithaca, N.Y.: Cornell University Press.

Bryant, Rebecca, and Christalla Yakinthou

2012 Cypriot Perceptions of Turkey. Istanbul: Turkish Economic and Social Studies Foundation.

Bubandt, Nils

2009 "From the Enemy's Point of View: Violence, Empathy, and the Ethnography of Fakes." Cultural Anthropology 24, no. 3: 553-88. https://doi.org/10.1111/j.15481360.2009.01040.x.

Butler, Judith

1990 Gender Trouble: Feminism and the Subversion of Identity. New York: Routledge.

1997a Excitable Speech: A Politics of the Performative. New York: Routledge.

1997b The Psychic Life of Power: Theories in Subjection. Stanford, Calif.: Stanford University Press.

Caspersen, Nina

2011 Unrecognized States: The Struggle for Recognition in the Modern International System. Cambridge, UK: Polity Press.

2018 "Recognition, Status Quo or Reintegration: Engagement with De Facto States." Ethnopolitics 17, no. 4: 373-89. https://doi.org/10.1080/17449057.2018.1495360. 
Cleto, Fabio

1999 "Introduction: Section II: Flaunting the Closet." In Camp: Queer Aesthetics and the Performing Subject: A Reader, edited by Fabio Cleto, 88-95. Ann Arbor: University of Michigan Press.

Cornell, Svante E.

2002 Autonomy and Conflict: Extraterritoriality and Separatism in the South CaucasusCases in Georgia. Uppsala, Sweden: Uppsala University Department of Peace and

Crǎciun, Magdalena Conflict Research.

2012 "Rethinking Fakes, Authenticating Selves." Journal of the Royal Anthropological Institute 18, no. 4: 846-63. https://doi.org/10.1111/j.1467-9655.2012.01795.x.

De Waal, Thomas

2018 Uncertain Ground: Engaging with Europe's De Facto States and Breakaway Territories. Brussels: Carnegie Europe.

Dyer, Richard

2002 The Culture of Queers. London: Routledge.

Fehérváry, Krisztina

2002 "American Kitchens, Luxury Bathrooms, and the Search for a 'Normal' Life in Postsocialist Hungary.” Ethnos 67, no. 3: 369-400. https://doi.org/10.1080/0014 184022000031211.

Friedman, Sara

2015 Exceptional States: Chinese Immigrants and Taiwanese Sovereignty. Berkeley: University of California Press.

Greenberg, Jessica

2011 "On the Road to Normal: Negotiating Agency and State Sovereignty in Postsocialist Serbia.” American Anthropologist 113, no. 1: 88-100. https://doi. org/10.1111/j.1548-1433.2010.01308.x.

Harvey, James, and Gareth Stansfield

2011 "Theorizing Unrecognized States: Sovereignty, Secessionism, and Political Economy." In Unrecognized States in the International System, edited by Nina Caspersen and Gareth Stansfield, 11-26. London: Routledge.

Ioannou, Gregoris

2020 Denktaş Güneyde: Kıbrıs Rum tarafinda bölünmenin normalleşmesi. Nicosia: Baranga. Isachenko, Daria

2012 The Making of Informal States: Statebuilding in Northern Cyprus and Transdniestria. New York: Palgrave Macmillan.

Jansen, Stef

2015 Yearnings in the Meantime: "Normal Lives" and the State in a Sarajevo Apartment Complex. Oxford: Berghahn.

Jovanović, Deana

2018 "The Politics of Simulation: Fake Repairs in a Serbian Industrial Town." Südosteuropa 66, no. 1: 27-44. https://doi.org/10.1515/soeu-2018-0003.

Ker-Lindsay, James

2018 "The Stigmatisation of De Facto States: Disapproval and 'Engagement without Recognition.” Ethnopolitics 17, no. 4: 362-72. https://doi.org/10.1080/17449057. 2018.1495363.

Kolstø, Pål

2000 Political Construction Sites: Nation-Building in Russia and the Post-Soviet States. Boulder, Colo.: Westview.

Kyris, George

2018 "Sovereignty and Engagement without Recognition: Explaining the Failure of Conflict Resolution in Cyprus.” Ethnopolitics 17, no. 4: 426-42. https://doi.org/10 $.1080 / 17449057.2018 .1495364$. 
Larkin, Brian

2004 "Degraded Images, Distorted Sounds: Nigerian Video and the Infrastructure of Piracy." Public Culture 16, no. 2: 289-314. https://doi.org/10.1215/08992363-162-289.

Markell, Patchen

2003 Bound by Recognition. Princeton, N.J.: Princeton University Press.

McConnell, Fiona

2009 "De Facto, Displaced, Tacit: The Sovereign Articulations of the Tibetan Government-in-Exile.” Political Geography 28, no. 6: 343-52. https://doi.org/10. 1016/j.polgeo.2009.04.001.

2016 Rehearsing the State: The Political Practices of the Tibetan Government in Exile. Chichester, UK: Wiley Blackwell.

Meadwell, Hudson

1999 "Secession, States and International Society." Review of International Studies 25, no. 3: 371-87. https://doi.org/10.1017/S026021059900371X.

Mitchell, Timothy

1990 "Everyday Metaphors of Power." Theory and Society 19, no. 5: 545-77. https://doi. org/10.1007/BF00147026.

1991 "The Limits of the State: Beyond Statist Approaches and Their Critics." American Political Science Review 85, no. 1: 77-96. https://doi.org/10.1017/ S0003055400271451.

Navaro-Yashin, Yael

2012 The Make-Believe Space: Affective Geography in a Postwar Polity. Durham, N.C.: Duke University Press.

Newell, Sasha

2013 "Brands as Masks: Public Secrecy and the Counterfeit in Côte d'Ivoire." Journal of the Royal Anthropological Institute 19, no. 1: 138-54. https://doi.org/10.1111/14679655.12007.

Newton, Esther

1972 Mother Camp: Female Impersonators in America. Chicago: University of Chicago Press.

Painter, Joe

2006 "Prosaic Geographies of Stateness." Political Geography 25, no. 7: 752-74. https:// doi.org/10.1016/j.polgeo.2006.07.004.

Pang, Laikwan

2008 “'China Who Makes and Fakes': A Semiotics of the Counterfeit." Theory, Culture, Papadakis, Yiannis and Society 25, no. 6: 117-40. https://doi.org/10.1177\%2F0263276408095547.

2006 "Nicosia after 1960: A River, a Bridge, and a Dead Zone." Global Media Journal: Mediterranean Edition 1, no. 1: 1-16.

Pegg, Scott

1998 International Society and the De Facto State. Aldershot: Ashgate.

Rajković, Ivan

2018 "For an Anthropology of the Demoralized: State Pay, Mock-labour, and Unfreedom in a Serbian Firm.” Journal of the Royal Anthropological Institute 24, no. 1: 47-70.

Reeves, Madeleine https://doi.org/10.1111/1467-9655.12751.

2013 "Clean Fake: Authenticating Documents and Persons in Migrant Moscow." Riza, Alper Ali American Ethnologist 40, no. 3: 508-24. https://doi.org/10.1111/amet.12036.

2015 "The Flag on the Mountain." Cyprus Mail, September 13. https://cyprus-mail. com/2015/09/13/the-flag-on-the-mountain/.

Rutherford, Danilyn

2012 Laughing at Leviathan: Sovereignty and Audience in West Papua. Chicago: University of Chicago Press. Kindle. 
Sontag, Susan

1999 “Notes on 'Camp.” In Camp: Queer Aesthetics and the Performing Subject: A Reader, edited by Fabio Cleto, 53-65. Ann Arbor: University of Michigan Press. Originally published in 1964.

Steinmüller, Hans, and Susanne Brandstädter, eds.

2015 Irony, Cynicism, and the Chinese State. New York: Routledge.

vom Bruck, Gabriele, and Barbara Bodenhorn, eds.

2006 An Anthropology of Names and Naming. Cambridge: Cambridge University Press.

Walker, R.B.J.

1993 Inside/Outside: International Relations as Political Theory. New York: Cambridge University Press.

1996 "Space/Time/Sovereignty." In Perspectives on Third-World Sovereignty: The Postmodern Paradox, edited by Mark E. Denham and Mark Owen Lombardi, 13-27. New York: St. Martin's Press.

Weber, Cynthia

1992 "Reconsidering Statehood: Examining the Sovereignty/Intervention Boundary." Review of International Studies 18, no. 3: 199-216. https://doi.org/10.1017/ S0260210500117231.

1995 Simulating Sovereignty: Intervention, the State, and Symbolic Exchange. Cambridge: Cambridge University Press.

1998 “Performative States." Millennium: Journal of International Studies 27, no. 1: 77-95. https://doi.org/10.1177\%2F03058298980270011101.

1999 Faking It: U.S. Hegemony in a "Post-Phallic" Era. Minneapolis: University of Minnesota Press.

White, Luise

2009 "What Does It Take to Be a State? Sovereignty and Sanctions in Rhodesia, 19651980.” In The State of Sovereignty: Territories, Laws, Populations, edited by Douglas Howland and Luise White, 148-68. Bloomington: Indiana University Press.

Wilson, Alice

2016 Sovereignty in Exile: A Saharan Liberation Movement Governs. Philaldelphia: University of Pennsylvania Press. 